\title{
Predicting m-shopping in the two largest m-commerce markets: The US and China
}

\author{
Myriam Ertz ${ }^{1 *}$, Myung-Soo Jo ${ }^{2}$, Ying Kong ${ }^{3}$ and Emine Sarigöllü ${ }^{2, *}$ \\ ${ }^{1}$ LaboNFC, University of Quebec in Chicoutimi, Canada; Myriam Ertz@uqac.ca \\ 2 McGill University, Canada; myung-soo.jo@ mcgill.ca \\ 3 Shantou University, Canada; ykong@mcgill.ca \\ ${ }^{4}$ LaboNFC, McGill University, Canada; emine.sarigollu@ mcgill.ca \\ *Correspondence: Myriam_Ertz@uqac.ca; Tel.: +1 4185455011
}




\title{
Predicting m-shopping in the two largest m-commerce markets: The US and China
}

\begin{abstract}
This research examines the factors affecting consumers' mobile shopping (m-shopping) intentions in China and the United States. Drawing on the hedonic-motivation system adoption model (HMSAM), it is proposed that perceived ease of use affects $m$-shopping intentions; furthermore, this relationship is mediated by perceived usefulness, perceived enjoyment, and control. A survey-based cross-sectional methodology involving a total of 720 respondents constitutes the methods of this study. In the US, 409 responses from American citizens or residents were obtained from surveys administered online by MTurk. In China, 311 responses from Chinese consumers were obtained from surveys administered online by Sojump. Perceived usefulness, an extrinsic motive, directly affects behavioral intentions, especially for Chinese consumers, and this effect is also much stronger and complemented by an indirect effect for the Chinese (relative to American) consumers. In contrast, intrinsic motives of joy and control, which are strongly impacted by perceived ease of use, do not influence intentions in either market. However, joy exerts an indirect influence on m-shopping intentions, but only for Chinese consumers. These results pertain to the specific context of mobile shopping and establish further the importance of distinguishing between utilitarian and hedonic factors, especially across different markets.
\end{abstract}

Keywords: mobile shopping; mobile commerce; hedonic motivation system adoption model; perceived ease of use; perceived usefulness; perceived enjoyment.

\section{Introduction}

The worldwide growth of electronic commerce is increasingly driven by mobile shopping (m-shopping), which encompasses both browsing and purchasing on mobile devices. One in four e-commerce dollars is spent on a mobile device (ComScore, 2018). Mobile commerce (m-commerce) is expected to reach 3.5 trillion USD in 2021 and make up staggering three-quarters of all e-commerce sales (eMarketer, 2017). The m-shopping trend is even more evident in fast emerging countries like China, where 91.2 percent of the Singles' Day sales came from mobile sales in 2017 (Lee, 2017). In established markets, such as the United States, m-shopping is also rising, although mobile devices seem mainly used for browsing rather than the actual purchase. In fact, during 2017's online holiday shopping, desktop accounted for $41 \%$ of all traffic but still commanded $60 \%$ of sales. In 2018, on Black Friday, mobile accounted for $34 \%$ of purchases, while on Cyber Monday, over $54 \%$ of retail visits came from mobile devices but only $28 \%$ of purchases. Therefore, mobile commerce is a platform of rising interest and importance worldwide (Chou, $\mathrm{Li}, \&$ Ho, 2018; Verkijika, 2018; Baabdullah et al., 2019; Al-Adwan, Alrousan, Al-Soud, \& AlYaseen, 2019).

As past research reported some resistance to mobile commerce in Western markets (Watson, McCarthy, \& Rowley, 2013), mobile commerce seems more widely accepted and practiced in countries like China than in the US (Lee, 2017). Classical technology acceptance variables such as perceived usefulness (i.e., the degree to which a person believes that using a particular system would enhance his or her job performance [Sultan, Rohm, \& Gao, 2009]), perceived ease of use (i.e., the degree to which a person believes 
that using a particular system would be free of effort [Davis, 1989, p. 320]), perceived enjoyment (i.e., the extent to which the activity of using a specific system is perceived enjoyable of its ability, apart from any performance consequences [Lowry et al., 2012, p. 7), perceived control (i.e., the user's perception of being in charge of the interaction [Agarwal \& Krahanna, 2000, p. 674]), and intentions might explain critical differences in this regard (Bruner \& Kumar, 2005). This study investigates consumers' intentions to use m-shopping in two countries China and the United States, comparatively. China and the US were selected not only because they are the two largest m-commerce markets worldwide and attract many marketers', investors', and business developers' attention, but also because there remain sharp differences in m-commerce adoption across both of these markets. The interest in comparing both markets if further motivated by past research highlighting key differences across both markets concerning digitization, such as in social media (Jiao, Ertz, Jo, \& Sarigöllü, 2018), or in mobile shopping continuance (Lu, Yu, Liu, $\&$ Wei, 2017). For all those reasons, the paper conducts a country comparison between those two markets.

Also, the paper seeks to answer a specific research gap in the literature. While extant research focused on the study of either hedonic factors (e.g., Liu, Yang, \& Ling, 2020) or utilitarian ones (e.g., Choi, 2018), especially with the classic technology of acceptance model (TAM), Unified theory of acceptance and use of technology (UTAUT), or UTAUT2 models (e.g., Sarkar, Chauhan, \& Khare, 2020; Sun \& Chi, 2018; Verkijika, 2018; Alrawi, Samy, Yusoff, \& Shanmugam, 2019; Shaw \& Seergueva, 2019; Marinković, Đorđević, \& Kalinić, 2020), or both factors but in limited settings (e.g., browsing) (e.g., Zheng, Men, Yang, \& Gong, 2019), the article explores to what extent $\mathrm{m}$-shopping has expanded beyond utilitarian use and is used for enjoyment as well. Such a transition is typically observed in the evolution of technology (Ko, Kim, \& Lee, 2009). Although some technology adoption model (e.g., UTAUT2) have considered pleasure-related factors to explain behavioral intentions, the perceived enjoyment constructs have usually been proposed only as extensions or modifications to the seminal models (e.g., Wong, Tan, Ooi, \& Lin, 2015; Liu, Yang, \& Ling, 2020), instead of constituting foundational aspects (Lowry et al., 2012; Yoo, Sanders, \& Cerveny, 2018) (e.g., from UTAUT to UTAUT2). This suggests that the hedonism-related variable is not a critical constitutive aspect of the model but rather an add-on. The current research posits that m-shopping entails a gamification aspect, much like what is proposed for online gaming (Lowry et al., 2012). Therefore, the study uses the hedonic-motivation system adoption model (HMSAM), which integrates from its inception both utilitarian and hedonic constructs in a cohesive whole (Lowry et al., 2012). More specifically, this model combines the constructs about classic technology adoption models, including the technology of the acceptance model with variables from gratification/gamification theories. As such, the HMSAM encompasses both the utilitarian and hedonic aspects of $\mathrm{m}$-shopping in its core foundations.

Past research focused singularly on either China or the US has identified key differences across markets regarding the resonance of utilitarian and hedonic factors. It appears that the Chinese are mainly influenced by perceived usefulness (i.e., utility) (Zhou, 2013, 2014; Yang, Wang, \& Wei, 2014), whereas Americans have a higher need to balance usefulness with hedonism (Ericson, Herring, \& Ungerman, 2014; Chick, 2015; Shankar et al., 2016). However, this has never been investigated formally, especially not with an allencompassing model as the HMSAM. Since the HMSAM comprises intrinsic variables 
referring to both motive types, it is ideal for exploring whether differences across both markets and identify more clearly what drives Chinese' higher m-shopping adoption. To this end, the conceptual model is tested empirically on data from China and the U.S. and offers implications based on the comparative findings. This study seeks to answer two questions:

1) What, if any, are the determinants of m-shopping?

2) How does the impact of m-shopping determinants differ between China and the US?

The key contribution of the study is to apply the HMSAM, which was developed initially to explain gaming, to the specific context of predicting $\mathrm{m}$-shopping adoption to understand better the differences in m-shopping adoption across China and the US. It is anticipated that, as this model subsumes both hedonic and utilitarian concepts, which might resonate differently with the Chinese and the Americans, there are increased possibilities to identify the key variables explaining differences in m-shopping adoption across those focal markets. The research offers several contributions to the literature. The consumerfocused and perception-based knowledge yielded by this study provides insights into the subjective perceptions lying at the crux of m-shopping behavior. This knowledge will enable innovators, entrepreneurs, and managers to modulate appropriate managerial features of their apps and platforms or influence key consumer variables to implement effectively thriving $\mathrm{m}$-shopping businesses. This study contributes to this objective in two ways, over and above the past literature.

First, the article explores and compares the critical determinants of m-shopping across two key markets in global m-commerce. Notably, the study provides deeper insights into the relative importance of utilitarian and hedonic variables in explaining $\mathrm{m}$-shopping using a model that places both kinds of predictors on an equal level of importance. In fact, although some technology adoption models, such as the unified theory of adoption and usage of technology (UTAUT), have considered pleasure-related factors to explain behavioral intentions, the perceived enjoyment constructs have usually been proposed only as extensions or modifications to the seminal models (e.g., Davis, 1989, Liu, Yang, \& Ling, 2020), as opposed to constituting focal aspects (Lowry et al., 2012; Yoo, Sanders, \& Cerveny, 2018; Alrawi, Samy, Yusoff, \& Shanmugam, 2019). In the case of UTAUT, this has resulted in UTAUT2, suggesting that hedonism-related variable is not a key constitutive aspect of the model but rather an add-on. The current research posits that $\mathrm{m}$ shopping entails a gamification aspect, much like what is proposed for online gaming (Lowry et al., 2012). Consequently, using the HMSAM model, which posits hedonismrelated predictors at its core, the study provides a clearer perspective on the relative importance of those hedonism-related factors compared to utilitarian ones.

Second, the paper shows key differences between consumers in China and the US in the HMSAM paths predicting m-shopping intentions.

Third, Du and Li (2019) showed that popular theories in mobile commerce are TAM, game theory, empirical analysis, expectation confirmation model, UTAUT/UTAUT2, commitment-trust theory, decision-making process, theory of reasoned action, network externalities, interpretive structural model, neural network and support vector machines. In contrast, the HMSAM has not been explored yet in the context of m-commerce despite its inherent value for placing utilitarian and hedonic benefits on an equal footing. The paper thus also contributes to past literature by investigating this model in the context of mcommerce. 


\section{Conceptual framework and hypotheses}

\subsection{The hedonic-motivation system adoption model (HMSAM)}

The hedonic-motivation system adoption model (HMSAM) combines technology acceptance and gratifications/gamification perspectives in an online context (Lowry et al., 2012). HMSAM provides an improved understanding of hedonic-motivation systems adoption (Santo \& Iswari, 2017), including online gaming, virtual worlds, online shopping, learning/education, online dating, digital music repositories, social networking, gamified systems, and general gamification (Karlsson \& Sveninge, 2017). HMSAM is not an extension of the technology acceptance model. Instead, it is based on an alternative theoretical perspective (Karlsson \& Sveninge, 2017), namely, flow theory (Csikszentmihalyi, 1989). Thus, it is instrumental in understanding gamification elements of online systems use (Karlsson \& Sveninge, 2017), and in this study, it enables to capture the hedonic aspect of m-shopping. Besides, as Lowry et al. (2012) suggested, the HMSAM remains a relatively parsimonious model to explain and predict the role of motivation in intentions to adopt the technology. However, since the HMSAM was initially developed for online gaming, we first had to adapt it to the $\mathrm{m}$-shopping context.

Five HMSAM measurement factors may affect Behavioral Intention to Use (and, Immersion in) an application; Perceived Usefulness (PU), Perceived Ease of Use (PEOU), Curiosity, Control, and Joy. PU and PEOU predict technology adoption intentions (Davis, 1989) and capture the utilitarian facet of m-shopping. Control and Joy related to the hedonic aspect of m-shopping (Lowry et al., 2012) and were also identified as crucial antecedents in online purchasing (Hubert et al., 2017). Curiosity, an antecedent to immersion, is not investigated in the current study since we do not investigate immersion. Detailed discussions on the four constructs and their relationships are presented below.

Fundamentally, this model differs from the alternatives (e.g., TAM, UTAUT, UTAUT2) in one significant aspect: the critical antecedent of intentions, i.e., PEOU, is related not only to PU and intentions but also to control and enjoyment. Therefore, drawing on the HMSAM, the research hypotheses are as follows in their application to m-shopping behavior:

\subsection{Hypothesis development}

\subsubsection{Antecedent factor}

Perceived ease of use (PEOU) is "the degree to which a person believes that using a particular system would be free of effort" (Davis, 1989, p. 320). We propose PEOU as an antecedent of perceived usefulness, perceived enjoyment, and control in keeping with Lowry et al. (2012). We also suggest PEOU as a direct determinant of behavioral intentions. Therefore, PEOU exerts both an indirect effect through PU, perceived enjoyment, and control on m-shopping intentions and directly affects those intentions.

The impact of PEOU on PU has been well-established in the literature (Lowry et al., 2012; Van der Heijden, 2004; Davis, 1989). PU measures extrinsic motivations. Thus, if consumers perceive that mobile devices are easy to use for shopping purposes, this perception should increase their perceived usefulness of the medium (Aldás-Manzano, 
2009) and directly enhance their intentions to use m-shopping (Watson, McCarthy, \& Rowley, 2013). Thus:

H1: Perceived ease of use relates positively to perceived usefulness.

Systems that are easy to use encourage enjoyment (Van der Heijden, 2004; Lee \& Quan, 2013). Besides, PEOU is a strong predictor of perceived enjoyment (Lowry et al., 2012; Merikivi, Tuunainen, \& Nguyen, 2017). We posit these findings can be extended to mshopping settings. M-shopping is primarily performed in short sessions while on the move or while doing other things simultaneously. Therefore, it is suggested that the perceived ease of use has a critical role in contributing to an enjoyable experience (Sultan, Rohm, \& Gao, 2009). M-shopping platforms should be easy to use to focus on shopping, and the pleasurable aspects, rather than dealing with user interface issues, mainly as m-shopping is performed on small touchscreens. Hence, we consider the role of PEOU as a direct antecedent to perceived enjoyment:

H2: Perceived ease of use relates positively to perceived enjoyment.

A system that is easier to use will naturally be considered as being more easily controllable (Lowry et al., 2012). Although it has been traditionally argued that perceived control determines perceptions about the ease of use of a system (e.g., Venkatesh, 2000), Lowry et al. (2012) provided empirical support for the reverse, that is, for the relationship between perceived ease of use and perceived control. In fact, the ease with which a system can be used will increase the controllability of that system. However, this link has not yet been validated empirically in the m-shopping context. Thus:

H3: Perceived ease of use relates positively to perceived control.

We further propose that PEOU (i.e., the antecedent factor) is related to perceived usefulness, perceived enjoyment, and control (Sultan, Rohm, \& Gao, 2009).

Perceived usefulness (PU). PU is defined as "the degree to which a person believes that using a particular system would enhance his or her job performance" (Davis, 1989, p. 320). In m-shopping, PU should be understood as usefulness in shopping effectiveness (Davis, 1989). Past research showed that utility, a concept related to PU, is positively associated with use intentions (Watson, McCarthy, \& Rowley, 2013). Likewise, in a gaming context, HMSAM posits a positive relationship between PU and intentions (Lowry et al., 2012). In the specific context of m-shopping, we might thus hypothesize the same because the PU of m-shopping in its utilitarian and hedonic sense can be explained from various aspects, including their 'always on' and 'portable' features (Wong et al., 2012). The PU of mshopping can also pertain to good deals and savings, for example. These can be accessed on mobile, primarily via geofencing, which signals users discounts and promotions offered by merchants located nearby (i.e., locational targeting of mobile promotions and special events) (Fong, Fang \& Luo, 2015; Ho, Dewan, \& Ho, 2020). This would translate into productivity and value for users spurring $\mathrm{m}$-shopping usage intentions. Thus: 
H4: Perceived usefulness of m-shopping relates positively to m-shopping intentions.

Perceived enjoyment. Perceived enjoyment or joy refers to "the extent to which the activity of using a specific system is perceived enjoyable of its ability, apart from any performance consequences" (Lowry et al., p. 7). It squarely fits with hedonism (Lowry et al., 2012), an essential construct in studying systems use (Lowry et al., 2012; Van der Heijden, 2004; Lin \& Bhattacherjee, 2010). The extant literature in consumer-oriented information systems depicts perceived enjoyment as one of the most critical drivers to use continuance (Lowry et al., 2012; Van der Heijden, 2004). With the advent of mobile technology, utilitarian and hedonic concepts have begun to intermingle (Shaw \& Sergueeva, 2019). For example, utilitarian browsing influences indirectly impulsive mobile purchases via hedonic browsing (Zheng, Men, Yang, \& Gong, 2019). For this reason, hedonic motivation is the foundation of the HMSAM (Lowry et al., 2012). A study by Merikivi, Tuunainen, and Nguyen (2017) on North American consumers further showed that joy is significantly related to behavioral intention. More specifically, Nysveen, Pedersen, and Thorbjørnsen (2005) emphasized how joy was a significant predictor of mshopping intentions. Thus:

H5: Perceived enjoyment of m-shopping relates positively to m-shopping intentions.

Perceived Control. Perceived control, or control, is "the user's perception of being in charge of the interaction" (Agarwal \& Karahanna, 2000, p. 674). The need for control is a fundamental basis for intrinsic motivation (Deci \& Ryan, 1985). Although the HMSAM model does not posit a direct link from control on intentions in gaming, past research suggest that such a relationship might hold in a m-shopping context (e.g., Watson, McCarthy, and Rowley, 2013). First, it should be mentioned that one of the most fundamental aspects of human existence is increasing personal control over one's environment (Bandura, 2001). Indeed, when the need or sense of control is fulfilled, consumers feel empowered, increasing intentions. Watson, McCarthy, and Rowley (2013) provided empirical evidence of the relationship between control and intentions to use QR codes, an essential part of mobile commerce. We might further deduce that users will be more likely to use it once they perceive to have control over mobile technology. Thus:

H6: Perceived control of m-shopping relates positively to $\mathrm{m}$-shopping intentions.

\subsubsection{Dependent variable}

Behavioral intent toward m-shopping is the key outcome variable in this study. Behavioral intent is defined as "the strength of one's intention to perform a specified behavior" (Fishbein \& Ajzen, 1975, p. 288). In this study, this construct relates to the consumers' intentions to engage in $\mathrm{m}$-shopping.

PEOU also exerts a direct effect on m-shopping intentions (Liang \& Yeh, 2011). When consumers perceive a system as easier to learn and use, they are more likely to accept it (Pikkarainen, Pikkarainen, Karjaluoto, \& Pahnila, 2004). To reduce consumers' physical effort, mobile devices must be easy to navigate and simple in design and processing power 
(Ranganathan \& Grandon, 2002). Additionally, online shopping websites must also be optimized for mobile usage (Yang, 2010). For example, mobile websites must have more explicit links to critical sites with fewer graphics loads to boost sales (Wong et al., 2012). Considering that several studies revealed explicitly or implicitly the linkage between PEOU with m-shopping intentions (e.g., Nysveen, Pedersen, \& Thorbjørnsen, 2005), we posit the following:

H7: Perceived ease of use relates positively to m-shopping intentions.

Since we posited a mediating influence of perceived usefulness, perceived joy, and control, we further propose an indirect effect of PEOU on intentions through these constructs in addition to the direct effect. The mediation of PU and perceived enjoyment on that relationship is predicted by the HMSAM (Lowry et al., 2012). However, this is not the case for perceived control. We nonetheless posit that control might also exert a mediation effect due to its relationship with PEOU (Lowry et al., 2012), on the one hand, and intention, on the other (Watson, McCarthy, \& Rowley, 2013). Hence:

H8: (a) Perceived ease of use relates positively to m-shopping intentions through (b) greater perceived usefulness, (c) greater perceived joy, and (d) greater control.

The conceptual model is shown in Figure 1.

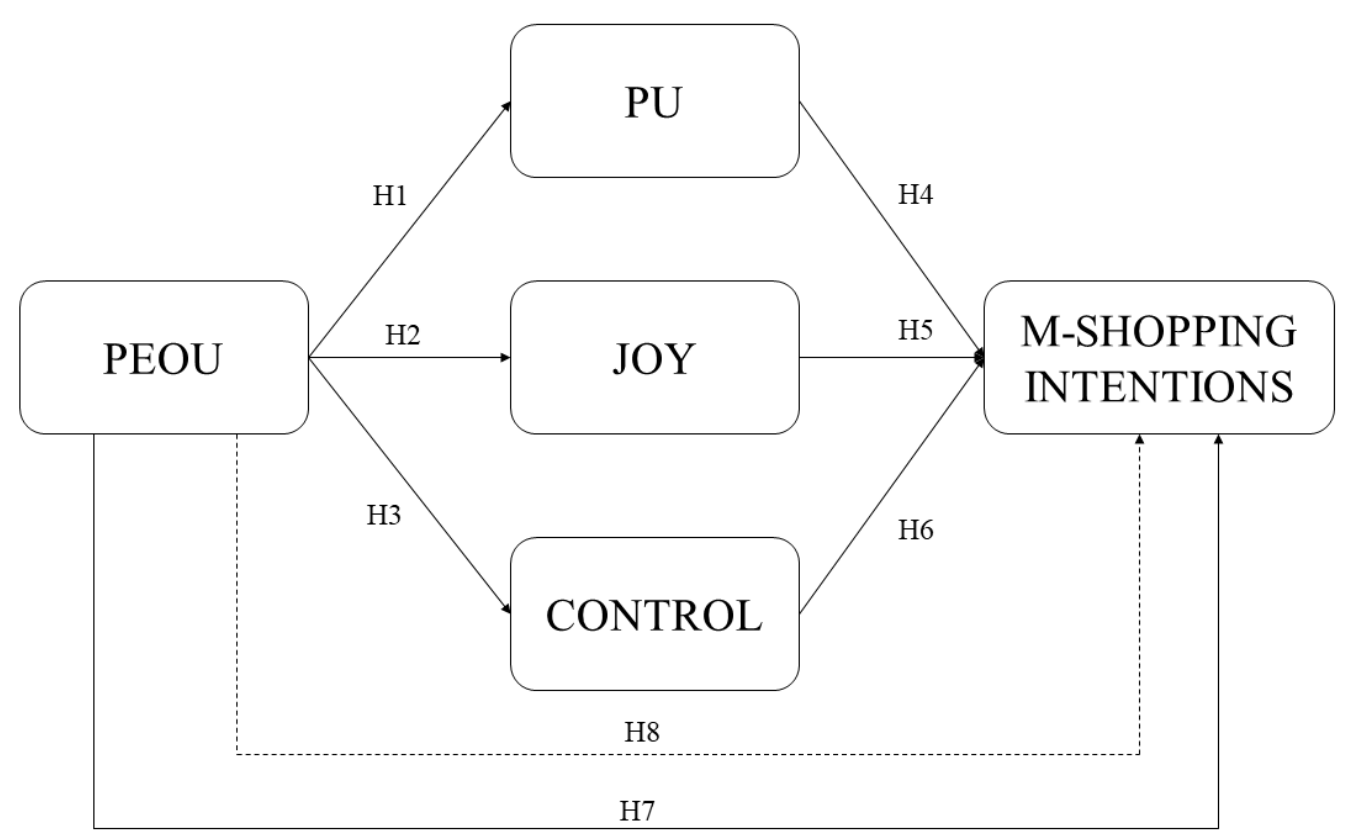

Note $:$ PEOU $=$ perceived ease of use, $\mathrm{PU}=$ perceived usefulness .

Figure 1. Conceptual model 


\subsection{A country comparison}

Despite claims of intersegmentation (Alqahtani, 2015), i.e., converging of cultures worldwide towards a common core culture (Jenkins, 2006), cultural differences in mobile marketing acceptance do persist (Sultan, Rohm, \& Gao, 2009). This explains the persistent need for country comparison studies in the m-commerce area (e.g., Verkijika, 2018).

China and the US were chosen based on size, access, and anticipated dissimilarities in m-shopping usage due to cultural differences. Besides, although both countries are the two largest $\mathrm{m}$-commerce markets, the Chinese market is much more active than the US market (eCommerce News, 2018). Only about $35 \%$ of e-commerce sales are conducted on a mobile device in the US, whereas this proportion rises to 56\% in China (Villegas, 2020). These statistics echo past studies that showed that consumers from emerging countries in general, and Asians, in particular, are the most active in m-shopping (Statista, 2014; Global Web Index, 2020). The appeal of mobile commerce in the Chinese market is also evidenced by the growth of Chinese mobile commerce platforms such as Taobao, JD.com, and Tmall (the top three commerce platforms making up a 78\% share) (Disfold, 2020).

In China, high governmental investments into the mobile infrastructure, including rural infrastructure (Leong, Pan, Newell, \& Cui, 2016), have made mobile more accessible to many consumers. Besides, the mobile phone manufacturing market grew extensively in China, thus increasing competition and driving down the prices of mobile phones (Jin \& Von Zedtwitz, 2008; Passport, 2016). Finally, China is a very protected market with limited exposure to foreign brands (e.g., Amazon, Walmart), which spurred the emergence of multiple local players who competed domestically before reaching a critical size that enabled them to expand globally, especially in neighboring countries (Disfold, 2020). Alibaba is a typical example of that strategy since it first evolved in the Chinese market until reaching a critical size which resulted in the creation of four distinct businesses: Taobao, Tmall, and Alibaba1688, dedicated to the Chinese market; and Alibaba.com as well as AliExpress focused exclusively on wholesale exports outside of China (Disfold, 2020).

Chinese in higher socio-economic status and urban areas are exposed to emerging technologies, such as mobile devices, to a similar extent as the US (Sultan, Rohm, \& Gao, 2009). Finally, in the US, there are often significant self-regulatory and public policy efforts related to m-shopping, but these efforts may be less so in China (Sultan, Rohm, \& Gao, 2009).

Collectively, the abovementioned factors suggest that consumers in the US and China are likely to exhibit some differences and similarities in their $\mathrm{m}$-shopping intentions. Hence, we study the factors that explain consumers' intention to engage in m-shopping across markets (i.e., the USA and China) and empirically test the model in Figure 1. Culture acts, therefore, as a valid explanatory context variable.

\section{Methodology}

\subsection{Research context and data collection}

The questionnaire was designed initially in English, then translated into Chinese, and backtranslated into English by three bilingual persons to ensure comparability. A pretest for the questionnaire was conducted with 30 students in large state universities located in China and the U.S, respectively. The pretest helped shorten the questionnaire and identify 
ambiguous wording. After revision, the final survey was implemented online MTurk in the U.S, and its equivalent Sojump, in China. The data was gathered from Chinese respondents in May 2017 and for American respondents in February 2017. Both Sojump and MTurk target regular consumers in both countries, but respondents need to be registered on those platforms to participate in the survey. The survey contained items to assess m-shopping intentions, perceived ease of use, perceived usefulness, perceived enjoyment, control, and behavioral intentions, aiming to estimate the model in Figure 1 and various other items about general $\mathrm{m}$-shopping behavior.

Although non-random procedures, the choice of Sojump and MTurk sample for this study were motivated by previous findings indicating that data obtained from these frames are at least as reliable as those obtained via traditional methods (Buhrmester, Kwang, \& Gosling, 2011; Casler, Bicker, \& Hackett, 2013). Besides, MTurk, in particular, helps researchers gather quality and diverse samples (Goodman \& Paolacci, 2017). Sojump being very similar to MTurk, the same reason motivated the choice of Sojump for the Chinese sample.

\subsection{Sample profile}

In the US, 409 responses from American citizens or residents were obtained from surveys administered online by MTurk. In China, 311 responses from Chinese consumers were obtained from surveys administered online by Sojump.

The average age was 28 years old, the sample was composed of a majority of males $(61.5 \%)$, with an average age of 29 years old. Also, compared to the Americans, the Chinese tend to be more frequently online (on the Internet) $\left(\chi^{2}=12.97, d f=4, \mathrm{p}<\right.$ $.05)$, own more mobile devices $\left(\chi^{2}=29.45, d f=3, \mathrm{p}<.001\right)$, spend more time on their mobile devices $\left(\chi^{2}=63.39, d f=2, \mathrm{p}<.001\right)$, change their mobile devices more frequently $\left(\chi^{2}=19.69, d f=3, \mathrm{p}<.001\right)$, purchase more frequently on their mobile devices $\left(\chi^{2}=23.27, d f=6, \mathrm{p}<.010\right)$, and spend more on their mobile devices $\left(\chi^{2}=\right.$ $70.49, d f=6, \mathrm{p}<.001)$. However, the Americans seem to be more satisfied with their telecommunications provider $\left(\chi^{2}=201.59, d f=4, \mathrm{p}<.001\right)$. More details per market are shown in Table 1.

Table 1. Demographic and behavioural characteristics of the sample

\begin{tabular}{|c|c|c|c|c|}
\hline Items & & $\begin{array}{c}\text { US } \\
\text { frequencies } \\
(\%) \\
\mathbf{N}=\mathbf{4 0 9}\end{array}$ & $\begin{array}{c}\text { China } \\
\text { Frequencies } \\
(\%) \\
\mathbf{N}=\mathbf{3 1 1}\end{array}$ & $\begin{array}{c}\text { Difference test } \\
\text { (Chi-square or t- } \\
\text { test) }\end{array}$ \\
\hline \multicolumn{5}{|l|}{ Gender } \\
\hline Male & & 62.3 & 57.1 & $\chi^{2}=35.47$ \\
\hline Female & & 37.7 & 42.9 & $p=0.000$ \\
\hline Average age & & 28 & 30 & \\
\hline \multicolumn{5}{|l|}{ Frequency of online presence } \\
\hline Once a month & & 4.6 & 4.2 & $\chi^{2}=12.97$ \\
\hline Once a week & & 5.4 & 3.6 & $\mathrm{p}=0.011$ \\
\hline Once every 2-3 days & & 5.9 & 1.3 & \\
\hline Every day & & 84.1 & 90.6 & \\
\hline $\begin{array}{l}\text { Mobile devices owned } \\
\text { smartphone, tablet) }\end{array}$ & (i.e., & & & \\
\hline 1 & & 32.3 & 18.4 & $\chi^{2}=29.45$ \\
\hline
\end{tabular}




\begin{tabular}{|c|c|c|c|}
\hline $2-3$ & 59.4 & 77.7 & $\mathrm{p}=0.000$ \\
\hline 4 or more & 8.3 & 3.9 & \\
\hline \multicolumn{4}{|c|}{$\begin{array}{l}\text { Average } \\
\text { device(s) per day }\end{array}$} \\
\hline Less than 2 hours & 11.0 & 3.2 & \multirow{3}{*}{$\begin{aligned} \chi^{2} & =63.39 \\
\mathrm{p} & =0.000\end{aligned}$} \\
\hline Between 2-4 hours & 52.6 & 31.1 & \\
\hline 5 hours or more & 36.4 & 65.7 & \\
\hline \multicolumn{4}{|c|}{$\begin{array}{l}\text { Frequency of mobile device(s) } \\
\text { upgrade }\end{array}$} \\
\hline In less than 1-year use & 6.6 & 11.3 & \multirow{4}{*}{$\begin{aligned} \chi^{2} & =19.69 \\
\mathrm{p} & =0.000\end{aligned}$} \\
\hline After a 1-year use & 34.7 & 35.9 & \\
\hline After more than 2-years use & 49.9 & 36.6 & \\
\hline After more time & 8.8 & 16.2 & \\
\hline \multicolumn{4}{|c|}{$\begin{array}{l}\text { Satisfaction with telecommunication } \\
\text { provider }\end{array}$} \\
\hline Very dissatisfied & 1.7 & 8.8 & \multirow{5}{*}{$\begin{array}{c}\chi^{2}=201.59 \\
p=0.000\end{array}$} \\
\hline Dissatisfied & 4.4 & 15.9 & \\
\hline Neutral & 21.8 & 55.5 & \\
\hline Satisfied & 48.9 & 17.5 & \\
\hline Very satisfied & 23.2 & 2.3 & \\
\hline \multicolumn{4}{|c|}{$\begin{array}{l}\text { Frequency of purchase on personal } \\
\text { mobile device }\end{array}$} \\
\hline Never & 0.0 & 2.9 & \multirow{7}{*}{$\begin{aligned} \chi^{2} & =23.27 \\
p & =0.001\end{aligned}$} \\
\hline Less than once a month & 20.8 & 15.0 & \\
\hline Once a month & 27.6 & 24.1 & \\
\hline Once every two weeks & 19.8 & 28.3 & \\
\hline Once a week & 17.4 & 13.7 & \\
\hline 2-3 times a week & 11.2 & 12.4 & \\
\hline Every day & 3.2 & 3.6 & \\
\hline \multicolumn{4}{|c|}{$\begin{array}{l}\text { Average amount spent on mobile } \\
\text { device per order }\end{array}$} \\
\hline Less than $\$ 50$ per order & 42.3 & 15.3 & \multirow{7}{*}{$\begin{aligned} \chi^{2} & =70.49 \\
p & =0.000\end{aligned}$} \\
\hline$\$ 51-\$ 100$ & 23.2 & 36.5 & \\
\hline$\$ 101-\$ 200$ & 15.2 & 29.9 & \\
\hline$\$ 201-\$ 300$ & 9.5 & 9.7 & \\
\hline$\$ 301-\$ 500$ & 7.8 & 5.2 & \\
\hline$\$ 501-\$ 1,000$ & 1.2 & 2.4 & \\
\hline More than $\$ 1,000$ per order & 0.7 & 1.0 & \\
\hline
\end{tabular}

\subsection{Measures}

Past literature treated constructs such as PEOU or PU as unidimensional and reflective (e.g., Yang, 2010; Groß, 2018), and accordingly, we considered them as such. This also enabled us to use Cronbach's alphas to extract the latent constructs. Each construct in the model was estimated by multiple items adapted from existing scales (Van der Heijden, 2004; Lowry et al., 2012) applied to the m-shopping context. All items were measured on a Likert-type scale (from $1=$ strongly disagree to $10=$ strongly agree). The different constructs of interest, their respective items (post confirmatory factor analysis [CFA]), and psychometric properties are shown in Appendix 1.

\subsection{Analysis}

The dependent variable is m-shopping intentions. The independent variables are the four constructs related to mobile commerce conations identified in Figure 1. 
Since the study takes a country comparison approach, it was essential to ensure that the measurement instrument is invariant across both market samples before testing the theoretical model (Steenkamp \& Baumgartner, 1998; Byrne, 2006). First, exploratory factor analyses (EFAs) (SPSS 23.0) using the Maximum Likelihood extraction method and Oblimin rotation technique showed that all the items loaded significantly on their intended factor in both datasets. We performed several confirmatory factor analyses with EQS (6.4) for reliability, unidimensionality, discriminant, and convergent validities of the measures (Anderson \& Gerbing, 1988). The CFAs were performed for both the U.S. and the Chinese samples through distinct measurement models.

Raw indicators need to be removed from further analysis if they had low factor loadings (below .40) (Nunnally \& Bernstein, 1994), large correlated error with other indicators, or if there were notable differences in factor loading structure between the two samples (Steenkamp \& Baumgartner, 1998). Only one raw indicator was removed based on these criteria (i.e., the first item of perceived ease of use: I find mobile device shopping to be trouble-free). As shown in Table 1, the fit indices collectively indicate an appropriate measurement model fit (Hu \& Bentler, 1999).

Contrast tests then assessed the measurement model's invariance on the overall pattern of factor loadings across the two samples (Byrne, 2006). An overall unconstrained measurement model was compared to that of a constrained one. The $\chi^{2}$ for the unconstrained model was $303.89(d f=186)$, and that for the constrained model was $319.30(d f=195)$. Since the $\chi^{2}$ difference, $15.41(d f=9)$, was not significant and that both the constrained and the unconstrained model had similar fit indices (NFI, CFI, or RMSEA), it was determined that the measurement model is invariant across both samples (Steenkamp \& Baumgartner, 1998). Invariance was further verified in pairwise comparisons on each factor loadings. There were no significant $\chi^{2}$ differences across the two samples except on the factor loadings of the two items whose constraints were relaxed, confirming the previously obtained results.

As shown in Appendix 1, all the loadings from latent factors to their respective indicators were significant and high (ranging from .62 to .98) across either constrained or unconstrained model and Chinese or U.S. sub-sample. Furthermore, the composite reliability coefficients and Cronbach's alphas were all above the threshold level of .60 (Bagozzi \& Yi, 1988), ensuring reliability for all the constructs. The average variances explained (AVE) for all the constructs were equal or greater than the cutoff level of .50 (Fornell \& Larcker, 1981) for evidence of convergent validity. These psychometric properties ensure convergent validity across both samples (Anderson \& Gerbing, 1988).

Discriminant validity was assessed with a pairwise restriction of models (Anderson \& Gerbing, 1988), an approach that has been used extensively in past studies to ensure discriminant validity (e.g., Labrecque, Zanjani, \& Milne, 2012; Ertz, Karakas, \& Sarigöllü, 2016). The correlation between each pair of factors was fixed to equal 1.0, and the significance of the chi-square change was tested (Anderson \& Gerbing, 1988). All the chi-square changes were significant, showing a better model fit for the model without these restrictions, evidence for discriminant validity (see Appendix 2).

Several techniques were used to rule out common methods bias (CMB). From an ex-ante perspective, we randomized questions in the questionnaire by using item rotation within constructs so that items appeared in different order across respondents. 
From a post hoc perspective, we used Harman's single-factor test, and found that a single factor yields a considerably worse model fit across both the U.S. $\left(\chi^{2}=527.98\right.$, $d f=103 ; \mathrm{p}=.000, \mathrm{NFI}=0.87 ; \mathrm{CFI}=0.89 ; \mathrm{IFI}=.89, \mathrm{GFI}=.89, \mathrm{AGFI}=.85, \mathrm{SRMR}$ $=0.049 ;$ RMSEA $=0.101)$, and Chinese $\left(\chi^{2}=824.88, d f=103 ; \mathrm{p}=.000, \mathrm{NFI}=0.66\right.$; $\mathrm{CFI}=0.69 ; \mathrm{IFI}=.69, \mathrm{GFI}=.82, \mathrm{AGFI}=.76, \mathrm{SRMR}=0.107 ; \mathrm{RMSEA}=0.131$ ) datasets. This indicates that no single factor accounts for the covariance between the measures, and thus, common method bias is not an issue.

\section{Results}

We tested the structural model with EQS 6.4 (Hu \& Bentler, 1999; Byrne, 2006) on both the U.S. and the China samples and found an appropriate fit between the data and the conceptual model (Hu \& Bentler, 1999) (see Appendix 1). Four out of seven hypotheses received significant support in each dataset, while one received support in only one sample, and the two remaining hypotheses were rejected (see Table 2).

The accepted hypotheses were H1, H2, H3, H4, and H7 for the U.S. sample and $\mathrm{H} 1, \mathrm{H} 2, \mathrm{H} 3$, and $\mathrm{H} 4$ for the Chinese sample. The lack of support for $\mathrm{H} 7$ in the Chinese sample may indicate a total mediation effect of the three mediating variables on the PEOU-intentions link. No support was found for H5 and H6 in both the U.S. and the Chinese samples.

The invariance of the structural model was then assessed across the two samples. To do so, a series of contrast tests were performed on the structural patterns across the two datasets (Byrne, 2006). As suggested by Jöreskog \& Sörbom (1999), the structural equivalence of the overall conceptual model was estimated through a comparison of the $\chi 2$ of the two models. One overall model was unconstrained. Another overall model was assessed with the constraint that the loadings for the independent variables on their corresponding dependent variables were similar across the two samples. The $\chi 2$ for the unconstrained model was $319.52(\mathrm{df}=192)$, whereas the $\chi 2$ for the constrained model was $369.55(\mathrm{df}=209)$. Since the $\chi 2$ difference of $50.03(\mathrm{df}=17)$ was significant $(\mathrm{p}<.001)$, the structural invariance of the overall conceptual model between the two samples was not established. This means that certain differences in path loadings exist across both samples (Hu \& Bentler, 1999).

The equivalence of the individual hypotheses was then assessed using a series of multi-group analyses (see Table 2, column 4). The multi-group contrast tests on each hypothesis showed that both samples differ on $\mathrm{H} 1$ and $\mathrm{H} 2$. According to these findings, the U.S. and Chinese consumers differ first regarding the extent to which the PEOU of m-shopping influences their perception of the usefulness of m-shopping. Specifically, Chinese consumers' PEOU of m-shopping increased their tendency to perceive m-shopping as useful while this effect is lower in the U.S. sample. Both markets also differ on the extent to which their PEOU of $\mathrm{m}$-shopping influences their

perceived enjoyment of m-shopping. U.S. consumers' perception of the ease of use of $\mathrm{m}$-shopping increased significantly more their tendency to perceive joy in $\mathrm{m}$-shopping.

We performed a bootstrapping analysis (SPSS 23.0) using the PROCESS macro (model 4) on 1000 bootstrap samples to assess the mediation effect and test for H8a-d. As shown in Table 2, H8 suggesting an indirect effect of the proposed mediators on the PEOU-intentions relationship was supported across both samples. More specifically, for the U.S. sample, the accepted hypotheses were H8a-b, whereas, 
for the Chinese sample, they were H8a-c. A series of t-tests on the standardized regression path coefficients showed the differences across sub-samples regarding the indirect effect. Overall, the Chinese respondents differed positively from the U.S. ones on the total indirect effect $(\mathrm{H} 8 \mathrm{a})$ and the more specific indirect effect via perceived usefulness nested in the overall indirect effect (H8b). Although the indirect effect via perceived joy $(\mathrm{H} 8 \mathrm{c})$ was significant for the Chinese, this effect did not differ significantly from the Americans.

Table 2. Results of multi-group analyses and model tests on individual country samples.

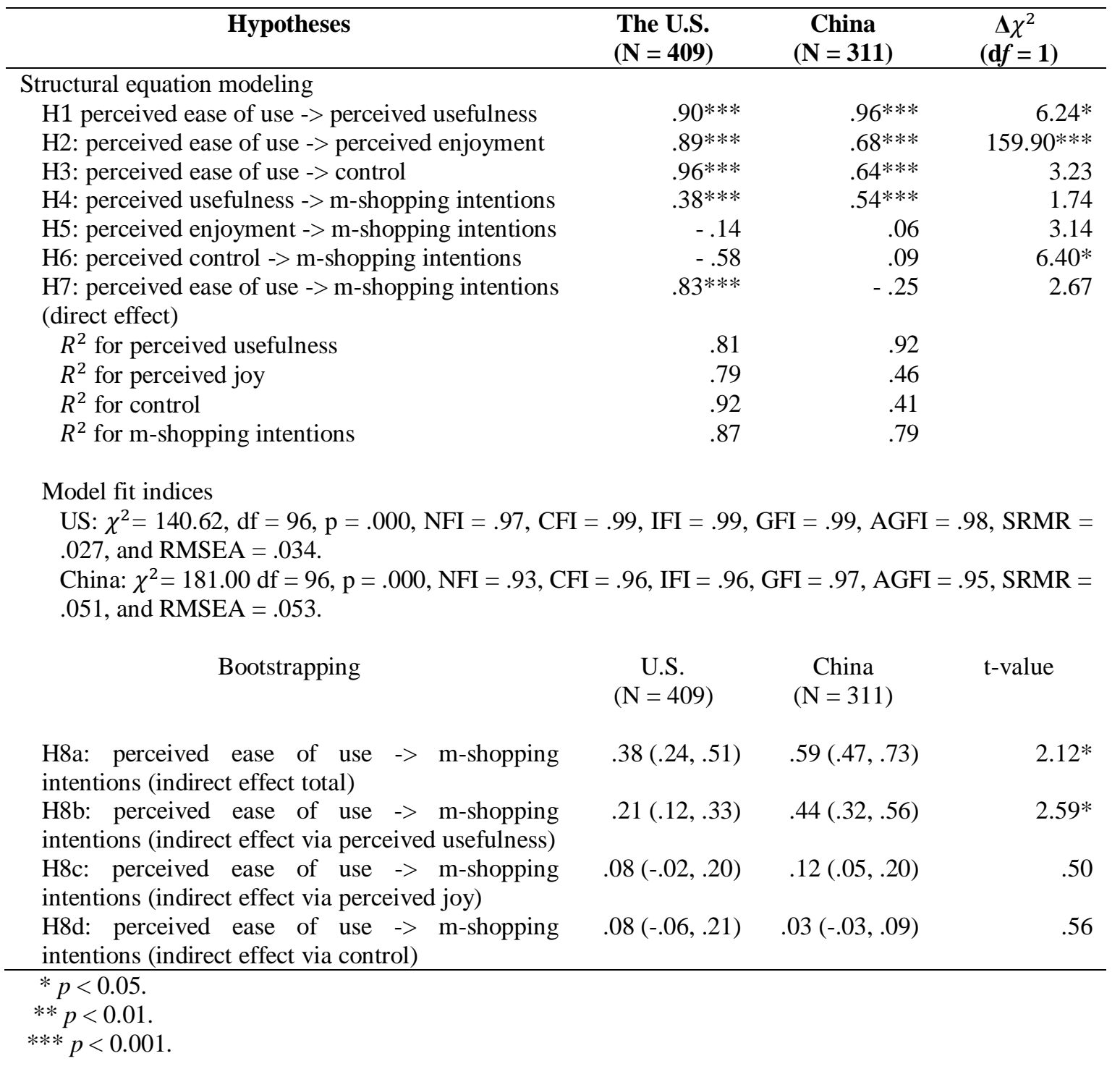

Five out of the eight hypothesized relationships under study were supported across both the U.S. and Chinese samples. The five hypotheses for which support was found included H1, H2, H3, H4, and H8. H7 was only supported in the U.S. dataset, whereas the remaining hypotheses (i.e., H5 and H6) were not supported in either sample. The new relationships posited by the HMSAM, namely the effect of PEOU on enjoyment 
and control, were validated in both markets. The effect of PEOU on enjoyment, control, and intentions is stronger for Americans than for the Chinese. However, the effect of PEOU on PU is stronger for the Chinese. Yet, only PEOU and PU impact intentions significantly, whereas joy and control do not. Considering that the indirect effect of PEOU on intentions is significantly stronger for the Chinese via PU, the route influencing Chinese' adoption of m-shopping is stronger and clearer via PU. In contrast, the route influencing Americans' adoption of m-shopping is less clear since, except for PEOU, no other variable exerts a significant direct or indirect effect on intentions.

This might potentially explain the slightly lower adoption of $\mathrm{m}$-shopping by Americans compared to the Chinese. The influence of PU for the Chinese is comparatively more decisive both directly and indirectly than for the Americans for whom the direct effect of PEOU on intentions does not compensate.

\section{Discussion and implications}

This study extends the extant literature on m-shopping by specifically regarding the similarities and differences between the two largest m-commerce countries that still show substantial dissimilarities in m-commerce adoption, China and the US.

Overall, across both markets, respondents' likelihood to perceive m-shopping as useful exerts a significant influence on m-shopping intentions. Unexpectedly, however, consumers' propensity to perceive joy or control in $\mathrm{m}$-shopping is not a significant influencer of $\mathrm{m}$-shopping intentions in either market, lending credit to research that emphasized the low explanatory power of enjoyment on m-shopping intentions in either emerging (Teo, Tan, Ooi, \& Lin, 2015) or established (Groß, 2018) markets. Conversely, perceived usefulness, as the utilitarian factor, is strongly related to m-shopping adoption. This suggests that the perception of utilitarian benefits and advantages related to m-shopping constitutes an essential priming factor for subsequent involvement in m-shopping, emphasizing the importance of distinguishing between the utilitarian and hedonic aspects in m-shopping (Hubert et al., 2017).

However, marked differences appear across the two markets. First, perceived ease of use relates positively to perceived usefulness, especially among the Chinese respondents, while perceived ease of use relates more positively to perceived enjoyment and control among the American respondents. Taken together, these results suggest that perceived ease of use influences more strongly utilitarian (hedonic) variables such as perceived usefulness among Chinese (American) consumers.

The stronger impact of PEOU on perceived usefulness among Chinese users is in line with past research, such as Zhou (2013, 2014), who showed that the Chinese were particularly sensitive to the usefulness of m-shopping in explaining their continuance with that technology. Drawing on categorization theory, other researchers delved deeper into those usefulness aspects by emphasizing the perceived consistency and perceived integration between mobile services and the Web as sources of usefulness shaping m-shopping adoption (Yang, Wang, \& Wei, 2014).

Likewise, the stronger impact of PEOU on hedonic variables such as joy and control among Americans aligns with past research. Several studies emphasized that m-shopping has the best chances to succeed in an American context if functional needs are balanced with hedonic needs (Ericson, Herring, \& Ungerman, 2014; Chick, 2015; 
Shankar et al., 2016). Even in the context of social media, the effect of intrinsic motivation is more substantial for Americans than for the Chinese (Jiao, Ertz, Jo, \& Sarigöllü, 2018). The stronger direct effect of PEOU on intentions also echoes past studies initiative in the United States, emphasizing that convenience is one of Americans' primary motivations to use mobile shopping (Ericson, Herring, \& Ungerman, 2014; Chick, 2015; Shankar et al., 2016).

Notably, except for Jiao, Ertz, Jo, and Sarigöllü (2018) in another context (i.e., social media), previous studies did not conduct a country comparison or cross-cultural study but emphasized crucial features of American and Chinese consumers. In light of these past findings, this study contributes to extant research by actually comparing both countries and revealing that intrinsic motives (joy and control) impact Chinese' intentions to use m-shopping very little compared to extrinsic motives (usefulness). Hence, the higher propensity of the Chinese to use m-shopping is related to the fact that they are more likely to perceive m-shopping as useful, which may hold for other emerging markets. Besides, this compound effect of PEOU and PU on intentions for Chinese consumers explains their higher levels of intentions, whereas, for Americans, m-shopping intentions are rather contingent on a direct effect of PEOU (i.e., convenience).

Therefore, the higher propensity to shop on mobile phones in China occurs because of heightened functionality perceptions. This is further evidenced by the stronger indirect effect of perceived usefulness on the PEOU-intentions relationship for Chinese rather than American consumers. Interestingly, and although this is not significantly different from the American sample, joy contributes to the indirect effect in the Chinese sample only, suggesting that the hedonic aspect of m-shopping, resulting from heightened PEOU, contributes to Chinese consumers' intentions. This result indicates that although not a direct predictor of intentions, enjoyment indirectly contributes to Chinese consumers' intentions.

This research shows a high proportion of similarities across markets consistent with past research on mobile settings (Sultan, Rohm, \& Gao, 2009; Pentina, Zhang, Bata, \& Chan, 2016; Jiao, Ertz, Jo, \& Sarigöllü, 2018). However, there also appear to be distinctive features across the two markets. In essence, Americans are more likely to use m-shopping if they directly perceive it to be easy to use. On the other hand, Chinese consumers are also concerned about PEOU but are even more concerned about how that convenience may translate into usefulness and how that convenience synergistically interacts with PU and, to a lesser extent, creates joy, which in turn leads to the slightly higher m-shopping use of the Chinese, commonly observed across both markets.

\section{Managerial implications}

Managers must be aware of the drivers as well as obstacles to consumer intentions of m-shopping across markets. In this regard, this study offers several critical implications for practitioners involved in $\mathrm{m}$-shopping programs and strategies.

\subsection{China}


The results suggest that extrinsic motives epitomized by perceived usefulness lie at the crux of the impact of perceived ease of use on m-shopping intentions, especially among Chinese consumers. Managers targeting emerging markets will thus want to craft mobile strategies that stimulate goal achievement and functionality such as optimized sorting, scrolling, recommender agent, augmented reality features, digital payment solutions (e.g., Ali Pay, Apple Pay, PayPal, cryptocurrencies) on m-shopping apps and web platforms, which then could lead to a greater perception of the usefulness of m-shopping, and, to a lesser extent, joy perception. This result implies that $\mathrm{m}$ shopping may be optimally stimulated by emphasizing the utilitarian aspects of that practice and improving ease of use to trigger joy in an emerging market such as China.

\subsection{United States}

Perceived ease of use is a key antecedent to m-shopping intentions, especially in markets such as the US, where other means of shopping (e.g., laptop, kiosks) are more widespread. Therefore, managers aiming to develop apps in established markets will need to focus on perceived ease of use as this variable is directly related to intentions to use. They will therefore need to integrate the abovementioned technologies focusing on user-friendliness rather than performativity. A design based on user experience (UX) might be particularly valuable in this regard.

\section{Study limitations and future research avenues}

The focus on the HMSAM as a conceptual framework means other causal sequences and variables not tested in this study could impact m-shopping intentions. Additionally, we used a non-random sampling procedure with MTurk and Sojump. Although they are proven sampling frames (Casler, Bickel, \& Hackett, 2013; Buhrmester, Kwang, \& Gosling, 2011), future research could be conducted with a broader and more representative sampling frame to examine differences related to age, socioeconomic status, and gender. Finally, this study highlighted key differences between China and the US (established and emerging markets) regarding the importance of utility in emerging contexts instead of established ones. Although these differences have been explained by infrastructure and political contingencies, they might relate to more profound cultural divergences. Future research might investigate these cultural differences regarding perceived ease of use and perceived usefulness in greater depth by using Hofstede's (Hofstede, 1980) dimensions, as in Chou, Li, and Ho (2018). Future research could investigate more directly the differences in extrinsic motives and intrinsic motives.

\section{References}

Agarwal, R., Karahanna, E. (2000). Time flies when you're having fun: Cognitive absorption and beliefs about information technology usage. MIS Quarterly, 24(4), 665-694. 
Al-Adwan, A. S., Alrousan, M., Al-Soud, A., \& Al-Yaseen, H. (2019). Revealing the black box of shifting from electronic commerce to mobile commerce: The case of Jordan. Journal of Theoretical and Applied Electronic Commerce Research, 14(1), 51-67.

Aldás-Manzano, J., Ruiz-Mafé, C., \& Sanz-Blas, S. (2009). Exploring individual personality factors as drivers of M-shopping acceptance. Industrial Management \& Data Systems, 109(6), 739-757.

Alqahtani, S. S. (2015). Segmentation of the Smart Phone Market among College Students: The Case of Saudi Arabia. World Journal of Social Sciences, 5(3), 110-122.

Alrawi, M. A. S., Samy, G. N., Yusoff, R. B. C. M., \& Shanmugam, B. (2019). Factors influencing the technology acceptance of mobile commerce in Malaysia by using the revised UTAUT model. International Journal of Recent Technology and Engineering, 8(4), 694-699.

Anderson, J. C., Gerbing, D.W. (1988). Structural equation modeling in practice: A review and recommended two-step approach. Psychological Bulletin, 103(3), 411-423.

Baabdullah, A.M., Alalwan, A.A., Rana, N.P., Kizgin, H., Patil, P. (2019). Consumer use of mobile banking (M-Banking) in Saudi Arabia: Towards an integrated model. International Journal of Information Management, 44, 38-52.

Bagozzi, R. P., Yi, Y. (1988). On the Evaluation of Structural Equation Models. Journal of the Academy of Marketing Science, 16, 74-94.

Bandura, A. (2001). Social cognitive theory: An agentic perspective. Annual Review of Psychology, 52(1), 1-26.

Bruner, G. C., Kumar, A. (2005). Explaining Consumer Acceptance of Handheld Internet Devices. Journal of Business Research, 58, 533-558.

Buhrmester, M., Kwang, T., Gosling, S.D. (2011). Amazon's Mechanical Turk: A new source of inexpensive, yet high-quality, data. In A.E. Kazdin (Ed.), Methodological issues and strategies in clinical research (pp. 133-139). American Psychological Association.

Byrne, B. M. (2006). Structural Equation Modeling with EQS: Basic Concepts, Applications, and Programming. Mahwah, NJ: Lawrence Erlbaum Associates Publishers.

Casler, K., Bickel, L., Hackett, E. (2013). Separate but equal? A comparison of participants and data gathered via Amazon's MTurk, social media, and face-to-face behavioral testing. Computers in Human Behavior, 29(6), 2156-2160.

Chick, A. (2015). Mobile shopping. http://whatisdictionary.com/mobileshopping/\#.WAboUk0zXIU

Choi, S. (2018). What promotes smartphone-based mobile commerce? Mobile-specific and self-service characteristics. Internet Research, 28(1), 105-122.

Chou, Y. H. D., Li, T. Y. D., \& Ho, C. T. B. (2018). Factors influencing the adoption of mobile commerce in Taiwan. International Journal of Mobile Communications, 16(2), 117-134.

ComScore (2018). Mobile share of commerce spending. Available online: https://www.statista.com/chart/12325/mobile-share-of-commerce-spending/ (accessed on 09-07-2020).

Csikszentmihalyi, M. (1989). Flow: The psychology of optimal experience. New York, NY: Harper and Row. 
Davis, F.D. (1989). Perceived usefulness, perceived ease of use, and user acceptance of information technology. MIS Quarterly, 13(3), 319-340.

Deci, E. L., \& Ryan, R. M. (1985). Intrinsic Motivation and Self-Determination in Human Behavior. New York, NY: Plenum.

Disfold (2020). Top 10 e-commerce sites in China 2020. October 7, 2021. https://disfold.com/top-e-commerce-sites-china/ (accessed on 20/01/2021).

Du, S., \& Li, H. (2019). The Knowledge Mapping of Mobile Commerce Research: A Visual Analysis Based on I-Model. Sustainability, 11(6), 1580.

eCommerce News (2018). UK is the third largest mcommerce market in the world. November 12, 2018. Available at: https://ecommercenews.eu/uk-is-the-third-largestmcommerce-market-in-the-world/ (accessed on 13/11/2020).

eMarketer (2018). Estimated worldwide mobile commerce sales. Available online: https://www.statista.com/chart/13139/estimated-worldwide-mobile-commercesales/ (accessed on 09-07-2020).

Ericson, L., Herring, L., \& Ungerman, K. (2014). Busting mobile-shopping myths. McKinsey Quarterly.

Ertz, M., Karakas, F., \& Sarigöllü, E. (2016). Exploring pro-environmental behaviors of consumers: An analysis of contextual factors, attitude, and behaviors. Journal of Business Research, 69(10), 3971-3980.

Fishbein, M., \& Ajzen, I. (1975). Belief, Attitude, Intention and Behavior: An Introduction to Theory and Research. Reading, MA: Addison-Wesley.

Fong, N. M., Fang, Z., \& Luo, X. (2015). Geo-conquesting: Competitive locational targeting of mobile promotions. Journal of Marketing Research, 52(5), 726-735.

Fornell, C., \& Larcker, D. F. (1981). Evaluating structural equation models with unobservable variables and measurement error. Journal of Marketing Research, 18(1), 39-50.

Global Web Index (2020). Connecting the dots: Consumer trends that will shape 2020. https://www.globalwebindex.com/hubfs/Downloads/Connecting the dots.pdf?utm campaign $=$ Trends $\% 202020 \& u t m \_$medium $=$email\&_hsmi $=79285410 \& \_h s e n c=p 2$ ANqtz-8BCSK9R5IBhJ2Bb3EPZBOqcz9UtF27kLoFeU0ZmTgSALIfQNkMwZm$\underline{\mathrm{u} 2835 \mathrm{hE0PFZ5HuEo1TmiXGOu} 48 \mathrm{nEh} 4 \mathrm{azFtB} 0 \mathrm{~A} \& u t m \_ \text {content=79285410\&utm }}$ source $=$ hs automation (Accessed on 20/02/2021).

Goodman, J. K., \& Paolacci, G. (2017). Crowdsourcing consumer research. Journal of Consumer Research, 44(1), 196-210.

Groß, M. (2018). Heterogeneity in consumers' mobile shopping acceptance: A finite mixture partial least squares modelling approach for exploring and characterising different shopper segments. Journal of Retailing and Consumer Services, 40, 8-18.

Ho, Y. J., Dewan, S., \& Ho, Y. C. (2020). Distance and Local Competition in Mobile Geofencing. Information Systems Research, 31(4), 1421-1442.

Hofstede, G. (1980). Motivation, leadership, and organization: do American theories apply abroad? Organizational Dynamics, 9(1), 42-63.

https://www.shopify.com/enterprise/mobilcommerce-future-trends (accessed on 1007-2020). 
Hu, L. T., \& Bentler, P. M. (1999). Cutoff criteria for fit indexes in covariance structure analysis: Conventional criteria versus new alternatives. Structural Equation Modeling: A Multidisciplinary Journal, 6(1), 1-55.

Hubert, M., Blut, M., Brock, C., Backhaus, C., \& Eberhardt, T. (2017). Acceptance of smartphone-based mobile shopping: Mobile benefits, customer characteristics, perceived risks, and the impact of application context. Psychology \& Marketing, 34(2), 175-194.

Jenkins, H. (2006). Convergence culture: Where old and new media collide. New York, NY: NYU Press.

Jiao, Y., Ertz, M., Jo, M.S., \& Sarigöllü, E. (2018). Social value, content value, and brand equity in social media brand communities: A comparison of Chinese and US consumers. International Marketing Review, 35(1), 18-41.

Jin, J., Von Zedtwitz, M. (2008). Technological capability development in China's mobile phone industry. Technovation, 28(6), 327-334.

Jöreskog, K., \& Sörbom, D. (1999). LISREL 8.30. Chicago: Scientific Software International.

Karlsson, R., \& Sveninge, A. (2017). Virtual Reality Locomotion: Four Evaluated Locomotion Methods. Available at: http://www.divaportal.org/smash/get/diva2:1144090/FULLTEXT02.pdf (accessed on 31/07/2019).

Ko, E., Kim, E. Y., \& Lee, E. K. (2009). Modeling consumer adoption of mobile shopping for fashion products in Korea. Psychology \& Marketing, 26(7), 669-687.

Labrecque, L. I., Zanjani, S. H., \& Milne, G. R. (2012). Authenticity in online Communications. In A. Close (Ed.) Online consumer behavior: Theory and research in social media, advertising, and e-tail (pp. 133-156). New York, NY: Taylor \& Francis Group.

Lee, C. (2017). Singles Day sales reach $\$ 38.2$ b across Chinese ecommerce platforms. November 12, ZD Net. Available online: https://www.zdnet.com/article/singles-daysales-reach-38-2b-across-chinese-ecommerce-platforms/ (accessed on 31/07/2019).

Leong, C. M. L., Pan, S. L., Newell, S., \& Cui, L. (2016). The Emergence of SelfOrganizing Commerce Ecosystems in Remote Villages of China: A Tale of Digital Empowerment for Rural Development. MIS Quarterly, 40(2), 475-484.

Liang, T. P., Yeh, Y. H. (2011). Effect of use contexts on the continuous use of mobile services: the case of mobile games. Personal and Ubiquitous Computing, 15(2), 187196.

Lin, C. P., Bhattacherjee, A. (2010). Extending technology usage models to interactive hedonic technologies: a theoretical model and empirical test. Information Systems Journal, 20(2), 163-181.

Liu, Z., Yang, J., \& Ling, L. (2020). Exploring the Influence of Live Streaming in Mobile Commerce on Adoption Intention From a Social Presence Perspective. International Journal of Mobile Human Computer Interaction, 12(2), 53-71.

Lowry, P. B., Gaskin, J., Twyman, N., Hammer, B., \& Roberts, T. (2012). Taking 'fun and games' seriously: Proposing the hedonic-motivation system adoption model (HMSAM). Journal of the Association for Information Systems, 14(11), 617-671.

Lu, J., Yu, C. S., Liu, C., \& Wei, J. (2017). Comparison of mobile shopping continuance intention between China and USA from an espoused cultural perspective. Computers in Human Behavior, 75, 130-146. 
Marinković, V., Đorđević, A., \& Kalinić, Z. (2020). The moderating effects of gender on customer satisfaction and continuance intention in mobile commerce: a UTAUTbased perspective. Technology Analysis \& Strategic Management, 32(3), 306-318.

Nunnally, J. C., \& Bernstein, I. H. (1994). Psychometric Theory, 3rd edition. New York, NY: McGraw-Hill.

Nysveen, H., Pedersen, P. E., \& Thorbjørnsen, H. (2005). Explaining intention to use mobile chat services: moderating effects of gender. Journal of consumer Marketing, 22(5), 247-256.

Passport (2016). Digital consumer - Connected commerce: China. Euromonitor International, June.

Pentina, I., Zhang, L., Bata, H., Chen, Y. (2016). Exploring privacy paradox in information-sensitive mobile app adoption: A cross-cultural comparison. Computers in Human Behavior, 65, 409-419.

Pikkarainen, T., Pikkarainen, K., Karjaluoto, H., \& Pahnila, S. (2004). Consumer acceptance of online banking: an extension of the technology acceptance model. Internet Research, 14(3), 224-235.

Ranganathan, C., \& Grandon, E. (2002). An exploratory examination of factors affecting online sales. Journal of Computer Information Systems, 42(3), 87-93.

Santo, S. C.; Iswari, N. M. S. (2017). Design and Development of Animal Recognition Application Using Gamification and Sattolo Shuffle Algorithm on Android Platform. International Journal of New Media Technology, 4(1), 46-53.

Sarkar, S., Chauhan, S., \& Khare, A. (2020). A meta-analysis of antecedents and consequences of trust in mobile commerce. International Journal of Information Management, 50, 286-301.

Shankar, V., Kleijnen, M., Ramanathan, S., Rizley, R., Holland, S., \& Morrissey, S. (2016). Mobile shopper marketing: Key issues, current insights, and future research avenues. Journal of Interactive Marketing, 34, 37-48.

Shaw, N., \& Sergueeva, K. (2019). The non-monetary benefits of mobile commerce: Extending UTAUT2 with perceived value. International Journal of Information Management, 45, 44-55.

Statista (2014). Asians are the most avid mobile shoppers. Available at: https://www.statista.com/chart/3057/mobile-share-of-e-commerce-transactions/ (accessed on 31/03/2020).

Steenkamp, J. E. M., \& Baumgartner, H. (1998). Assessing Measurement Invariance in Cross-National Consumer Research. Journal of Consumer Research, 25(1), 78-90.

Sultan, F., Rohm, A. J., \& Gao, T. T. (2009). Factors influencing consumer acceptance of mobile marketing: a two-country study of youth markets. Journal of Interactive Marketing, 23(4), 308-320.

Sun, J., \& Chi, T. (2018). Key factors influencing the adoption of apparel mobile commerce: an empirical study of Chinese consumers. The journal of the Textile Institute, 109(6), 785-797.

Teo, A. C., Tan, G. W. H., Ooi, K. B., \& Lin, B. (2015). Why consumers adopt mobile payment? A partial least squares structural equation modelling (PLS-SEM) approach. International Journal of Mobile Communications, 13(5), 478-497.

Van der Heijden, H. (2004). User acceptance of hedonic information systems. MIS Quarterly, 28(4), 695-704. 
Venkatesh, V. (2000). Determinants of perceived ease of use: Integrating control, intrinsic motivation, and emotion into the technology acceptance model. Information Systems Research, 11(4), 342-365.

Verkijika, S. F. (2018). Factors influencing the adoption of mobile commerce applications in Cameroon. Telematics and Informatics, 35(6), 1665-1674.

Villegas, S. (2020). An introduction to mobile commerce in China. Mobile Payments Today, April 21, 2020. https://www.mobilepaymentstoday.com/blogs/anintroduction-to-mobile-commerce-in-china/ (accessed on 20/01/2021).

Watson, C., McCarthy, J., \& Rowley, J. (2013). Consumer attitudes towards mobile marketing in the smart phone era. International Journal of Information Management, 33(5), 840-849.

Wong, C. H., Lee, H. S., Lim, Y. H., Chua, B. H., \& Tan, G. W. H. (2012). Predicting the consumers' intention to adopt mobile shopping: an emerging market perspective. International Journal of Network and Mobile Technologies, 3(3), 24-39.

Wong, C. H., Tan, G. W. H., Ooi, K. B., \& Lin, B. (2015). Mobile shopping: the next frontier of the shopping industry? An emerging market perspective. International Journal of Mobile Communications, 13(1), 92-112.

Yang, K. (2010). Determinants of US consumer mobile shopping services adoption: implications for designing mobile shopping services. Journal of Consumer Marketing, 27(3), 262-270.

Yang, S., Wang, Y., \& Wei, J. (2014). Integration and consistency between web and mobile services. Industrial Management \& Data Systems, 17, e202017002.

Yoo, C. W., Sanders, G. L., \& Cerveny, R. P. (2018). Exploring the influence of flow and psychological ownership on security education, training and awareness effectiveness and security compliance. Decision Support Systems, 108, 107-118.

Zheng, X., Men, J., Yang, F., \& Gong, X. (2019). Understanding impulse buying in mobile commerce: An investigation into hedonic and utilitarian browsing. International Journal of Information Management, 48, 151-160.

Zhou, T. (2013). An empirical examination of continuance intention of mobile payment services. Decision Support Systems, 54(2), 1085-1091.

Zhou, T. (2014). Understanding the determinants of mobile payment continuance usage. Industrial Management \& Data Systems, 114(6), 936-948.

Appendix 1. Confirmatory factor analyses for US and Chinese data.

\begin{tabular}{cccccc}
\hline $\begin{array}{c}\text { Constructs and items } \\
\text { (Van der Heijden, 2004; } \\
\text { Lowry et al., 2012) }\end{array}$ & $\begin{array}{c}\text { Mean } \\
\text { (s.d.) } \\
\text { USA }\end{array}$ & $\begin{array}{c}\text { Mean } \\
\text { (s.d.) } \\
\text { China }\end{array}$ & $\begin{array}{c}\text { Difference } \\
\text { test (F-value) }\end{array}$ & $\begin{array}{c}\text { Std. loadings } \\
\text { USA }\end{array}$ & $\begin{array}{c}\text { Std. loadings } \\
\text { China }\end{array}$ \\
\hline Perceived ease of use & 7.11 & 7.11 & n.s. & $\begin{array}{c}(\alpha=.91, \rho= \\
.89, \text { AVE }=\end{array}$ & $\begin{array}{c}(\alpha=.76, \rho= \\
.74, \text { AVE }= \\
\end{array}$ \\
$(1.94)$ & $(1.58)$ & & $.73)$ & $.50)$
\end{tabular}




\begin{tabular}{|c|c|c|c|c|c|}
\hline $\begin{array}{l}\text { I find it easy to shop on my } \\
\text { mobile device for what I } \\
\text { want. }\end{array}$ & $\begin{array}{c}6.97 \\
(2.22)\end{array}$ & $\begin{array}{c}6.81 \\
(2.21)\end{array}$ & n.s. & .88 & .63 \\
\hline $\begin{array}{l}\text { Learning to shop on my } \\
\text { mobile device is easy for me. }\end{array}$ & $\begin{array}{c}7.36 \\
(2.09)\end{array}$ & $\begin{array}{c}8.01 \\
(1.97)\end{array}$ & $17.78 * * *$ & .81 & .74 \\
\hline $\begin{array}{c}\text { It is simple to shop with my } \\
\text { mobile device }\end{array}$ & $\begin{array}{l}7.36 \\
(2.17)\end{array}$ & $\begin{array}{c}7.88 \\
(1.94)\end{array}$ & $10.35^{* *}$ & .87 & .71 \\
\hline Perceived usefulness & $\begin{array}{c}6.71 \\
(2.02)\end{array}$ & $\begin{array}{c}7.12 \\
(1.82)\end{array}$ & $7.64 * *$ & $\begin{array}{c}(\alpha=.87, \rho= \\
.86, \mathrm{AVE}= \\
\quad .68)\end{array}$ & $\begin{array}{c}(\alpha=.84, \rho= \\
.84, \mathrm{AVE}= \\
.64)\end{array}$ \\
\hline $\begin{array}{l}\text { Mobile device shopping } \\
\text { increases my productivity. }\end{array}$ & $\begin{array}{l}6.50 \\
(2.30)\end{array}$ & $\begin{array}{c}6.84 \\
(2.29)\end{array}$ & n.s. & .73 & .70 \\
\hline $\begin{array}{l}\text { Using mobile device } \\
\text { shopping enhances my } \\
\text { effectiveness in purchases. }\end{array}$ & $\begin{array}{c}6.56 \\
(2.36)\end{array}$ & $\begin{array}{l}7.03 \\
(2.06)\end{array}$ & $7.62 * *$ & .85 & .78 \\
\hline $\begin{array}{l}\text { I find mobile device } \\
\text { shopping to be useful in my } \\
\text { daily life. }\end{array}$ & $\begin{array}{c}6.98 \\
(2.21)\end{array}$ & $\begin{array}{c}7.48 \\
(1.98)\end{array}$ & $9.80 * *$ & .88 & .91 \\
\hline Perceived enjoyment & $\begin{array}{c}6.92 \\
(2.03)\end{array}$ & $\begin{array}{c}6.73 \\
(1.84)\end{array}$ & n.s. & $\begin{array}{c}(\alpha=.94, \rho= \\
.94, \mathrm{AVE}= \\
.79)\end{array}$ & $\begin{array}{c}(\alpha=.94, \rho= \\
.95, \mathrm{AVE}= \\
.82)\end{array}$ \\
\hline $\begin{array}{l}\text { I find mobile device } \\
\text { shopping to be enjoyable. }\end{array}$ & $\begin{array}{l}7.09 \\
(2.17)\end{array}$ & $\begin{array}{c}6.74 \\
(2.07)\end{array}$ & $4.83^{*}$ & .87 & .92 \\
\hline $\begin{array}{l}\text { I have fun using mobile } \\
\text { device shopping. }\end{array}$ & $\begin{array}{l}6.70 \\
(2.35)\end{array}$ & $\begin{array}{c}6.80 \\
(2.09)\end{array}$ & n.s. & .86 & .97 \\
\hline $\begin{array}{l}\text { The m-shopping experience } \\
\text { is enjoyable. }\end{array}$ & $\begin{array}{c}6.86 \\
(2.18)\end{array}$ & $\begin{array}{c}6.71 \\
(1.90)\end{array}$ & n.s. & .91 & .91 \\
\hline $\begin{array}{l}\text { Mobile device shopping } \\
\text { leaves me satisfied. }\end{array}$ & $\begin{array}{c}6.89 \\
(2.19)\end{array}$ & $\begin{array}{c}6.62 \\
(1.94)\end{array}$ & n.s. & .91 & .81 \\
\hline Control & $\begin{array}{c}7.15 \\
(1.99)\end{array}$ & $\begin{array}{c}6.72 \\
(1.85)\end{array}$ & $8.59 * *$ & $\begin{array}{l}(\alpha=.91, \rho= \\
.91, \mathrm{AVE}= \\
.76)\end{array}$ & $\begin{array}{c}(\alpha=.78, \rho= \\
.81, \mathrm{AVE}= \\
.59)\end{array}$ \\
\hline $\begin{array}{l}\text { I have a lot of control on } \\
\text { mobile device shopping. }\end{array}$ & $\begin{array}{l}7.01 \\
(2.22)\end{array}$ & $\begin{array}{c}6.17 \\
(2.44)\end{array}$ & $23.02 * * *$ & .87 & .62 \\
\hline $\begin{array}{c}\text { I can choose freely what I } \\
\text { want to see or do via mobile } \\
\text { device shopping. }\end{array}$ & $\begin{array}{c}7.24 \\
(2.14)\end{array}$ & $\begin{array}{l}7.17 \\
(2.15)\end{array}$ & n.s. & .88 & .83 \\
\hline $\begin{array}{l}\text { I am allowed to control my } \\
\text { interaction on mobile device } \\
\text { shopping. }\end{array}$ & $\begin{array}{l}7.19 \\
(2.12)\end{array}$ & $\begin{array}{c}6.80 \\
(2.07)\end{array}$ & $6.08 *$ & .87 & .83 \\
\hline Behavioral intentions & $\begin{array}{l}7.56 \\
(2.00)\end{array}$ & $\begin{array}{c}7.79 \\
(1.83)\end{array}$ & n.s. & $\begin{array}{c}(\alpha=.94, \rho= \\
.94, \mathrm{AVE}= \\
.84)\end{array}$ & $\begin{array}{c}(\alpha=.96, \rho= \\
.96, \mathrm{AVE}= \\
.90)\end{array}$ \\
\hline $\begin{array}{l}\text { I would plan on using mobile } \\
\text { device shopping in the future. }\end{array}$ & $\begin{array}{l}7.48 \\
(2.17)\end{array}$ & $\begin{array}{c}7.56 \\
(1.95)\end{array}$ & n.s. & .89 & .90 \\
\hline $\begin{array}{l}\text { I would intend to continue } \\
\text { using mobile device } \\
\text { shopping in the future. }\end{array}$ & $\begin{array}{l}7.50 \\
(2.17)\end{array}$ & $\begin{array}{l}7.85 \\
(1.90)\end{array}$ & $4.70 *$ & .94 & .98 \\
\hline
\end{tabular}


I expect my use of mobile device shopping to continue in the future.
$7.64 \quad 7.99$

(2.08)

Measurement model fit indices:

US Model: $\chi^{2}=128.89, \mathrm{df}=93, \mathrm{p}=.010, \mathrm{NFI}=.97, \mathrm{CFI}=.99, \mathrm{IFI}=.99, \mathrm{GFI}=.99$, AGFI $=.98$, $\mathrm{SRMR}=.024$, and RMSEA $=.031$.

China Model: $\chi^{2}=177.58 \mathrm{df}=93, \mathrm{p}=.000, \mathrm{NFI}=.93, \mathrm{CFI}=.96, \mathrm{IFI}=.96, \mathrm{GFI}=.97$, AGFI $=.95$, SRMR $=.047$, and RMSEA $=.054$.

Appendix 2. Chi-square difference tests for assessing discriminant validity

\begin{tabular}{|c|c|c|c|c|}
\hline & \multicolumn{2}{|c|}{ USA $(N=409)$} & \multicolumn{2}{|c|}{ China $(N=311)$} \\
\hline & $\chi^{2}$ Value & $\Delta \chi^{2}(\mathrm{~d} f=1)$ & $\chi^{2}$ Value & $\Delta \chi^{2}(\mathrm{~d} f=1)$ \\
\hline Unconstrained model $(\mathrm{d} f=93)$ & 128.89 & --- & 177.58 & --- \\
\hline \multicolumn{5}{|l|}{ Constrained model $(\mathrm{d} f=94)$} \\
\hline JOY-CONTROL & 214.68 & $85.79 * * *$ & 181.68 & $52.79 * * *$ \\
\hline JOY-PEOU & 220.37 & $91.48 * * *$ & 185.36 & $56.47 * * *$ \\
\hline JOY-PU & 179.24 & $50.35^{* * *}$ & 196.22 & $67.33 * * *$ \\
\hline JOY-INTENTIONS & 195.66 & $66.77 * * *$ & 197.04 & $68.15^{* * *}$ \\
\hline CONTROL - PEOU & 258.91 & $130.02 * * *$ & 179.69 & $50.80 * * *$ \\
\hline CONTROL - PU & 181.94 & $53.05 * * *$ & 180.97 & $52.08 * * *$ \\
\hline CONTROL - INTENTIONS & 210.47 & $81.58 * * *$ & 182.64 & $53.75 * * *$ \\
\hline PEOU - PU & 188.15 & $59.26 * * *$ & 195.61 & $66.72 * * *$ \\
\hline PEOU - INTENTIONS & 239.24 & $110.35^{* * *}$ & 194.76 & $65.87 * * *$ \\
\hline PU - INTENTIONS & 189.60 & $60.71 * * *$ & 214.83 & $85.94 * * *$ \\
\hline
\end{tabular}

Notes: $d f=$ degrees of freedom; PEOU $=$ Perceived ease of use; $\mathrm{PU}=$ Perceived usefulness.

$* p<0.05$.

$* * p<0.01$.

$* * * p<0.001$. 